\title{
Activation of the Alternative Complement Pathway by Exposure of Phosphatidylethanolamine and Phosphatidylserine on Erythrocytes from Sickle Cell Disease Patients
}

\author{
Robert H. Wang, * George Phillips, Jr., ${ }^{*}$ M. Edward Medof," and Carolyn Mold * \\ ${ }^{*}$ Department of Microbiology, University of New Mexico, Albuquerque, New Mexico 87131; ${ }^{\ddagger}$ Department of Medicine, Duke University \\ School of Medicine, Durham, North Carolina 27710; and $\$$ Institute of Pathology, Case Western Reserve University, Cleveland, Ohio 44106
}

\begin{abstract}
Deoxygenation of erythrocytes from sickle cell anemia (SCA) patients alters membrane phospholipid distribution with increased exposure of phosphatidylethanolamine (PE) and phosphatidylserine (PS) on the outer leaflet. This study investigated whether altered membrane phospholipid exposure on sickle erythrocytes results in complement activation. In vitro deoxygenation of sickle but not normal erythrocytes resulted in complement activation measured by $\mathrm{C} 3$ binding. Additional evidence indicated that this activation was the result of the alterations in membrane phospholipids. First, complement was activated by normal erythrocytes after incubation with sodium tetrathionate, which produces similar phospholipid changes. Second, antibody was not required for complement activation by sickle or tetrathionate-treated erythrocytes. Third, the membrane regulatory proteins, decay-accelerating factor (CD55) and the $\mathrm{C3b} / \mathrm{C4b}$ receptor (CD35), were normal on sickle and tetrathionate-treated erythrocytes. Finally, insertion of PE or PS into normal erythrocytes induced alternative pathway activation. SCA patients in crisis exhibited increased plasma factor $\mathrm{Bb}$ levels compared with baseline, and erythrocytes isolated from hospitalized SCA patients had increased levels of bound $\mathrm{C} 3$, indicating that alternative pathway activation occurs in vivo. Activation of complement may be a contributing factor in sickle crisis episodes, shortening the life span of erythrocytes, and decreasing host defense against infections. (J. Clin. Invest. 1993. 92:1326-1335.) Key words: phospholipid • membrane $\bullet \mathrm{C} 3 \cdot$ factor B
\end{abstract}

\section{Introduction}

Sickle cell anemia (SCA $)^{1}$ is a genetic disease resulting from a single amino acid change in the $\beta$-globin subunit of hemoglobin (1). This abnormal hemoglobin is termed hemoglobin $S$ $(\mathrm{Hb} \mathrm{S})$, and homozygous individuals ( $\mathrm{Hb} \mathrm{SS}$ ) develop a chronic hemolytic anemia, chronic and progressive tissue and organ damage, and acute painful vasoocclusive crises. Erythrocytes from SCA patients when exposed to low oxygen pressure

Address correspondence and reprint requests to Dr. Carolyn Mold, Department of Microbiology, University of New Mexico School of Medicine, Albuquerque, NM 87131.

Received for publication 12 October 1992 and in revised form 22 April 1993.

\section{J. Clin. Invest.}

(c) The American Society for Clinical Investigation, Inc.

$0021-9738 / 93 / 09 / 1326 / 10 \$ 2.00$

Volume 92, September 1993, 1326-1335 become deformed into a sickle shape as a result of polymerization of $\mathrm{Hb} \mathrm{S}$ within the cell. Sickle erythrocytes have a shorter life span than normal erythrocytes and are less elastic, more easily trapped in capillaries, and more prone to physiological insults $(1,2)$. Sickle erythrocytes also have altered membrane phospholipid distribution after deoxygenation (3-5).

Phospholipids on normal human erythrocytes are asymmetrically distributed across the bilayers of the cell membrane ( 5 , 6). Phosphatidylcholine (PC), sphingomyelin, and $<10 \%$ of the total phosphatidylethanolamine (PE) are located in the external leaflet. Most of the PE and all of the phosphatidylserine (PS) are located on the inner leaflet of the membrane bilayer. Deoxygenation of $\mathrm{Hb}$ SS erythrocytes results in increased exposure of PE and PS on the outer leaflet (3-5). The abnormal exposure of PS on sickle erythrocytes has been related to increased adherence to endothelial cells (2), procoagulant activity (7), and adherence to mononuclear phagocytic cells $(8,9)$.

Patients with SCA are susceptible to recurrent bacterial infections, particularly with Streptococcus pneumoniae (10). The higher propensity for bacterial infections has been attributed to decreased splenic function (11). Abnormal opsonic activity (12-14) and evidence of alternative complement pathway activation (15-18) have been observed in serum from patients with SCA, suggesting that decreased serum complement may also contribute to the higher risk of bacterial infections. The source of this complement activation has not been determined.

The alternative complement pathway is a primary host defense mechanism, which can be activated by bacterial polysaccharides, virus-infected cells, and other substances in the absence of specific antibodies $(19,20)$. Upon activation, C3b molecules are deposited covalently on the activator surface leading to opsonization and formation of the lytic membrane attack complex. Liposomes containing PE (21) and/or PS (22-24) activate the alternative complement pathway in human serum. $\mathrm{C} 3 \mathrm{~b}$ deposition on normal host cells is inhibited by membrane regulatory proteins, including decay-accelerating

1. Abbreviations used in this paper: $\mathrm{CR} 1, \mathrm{C} 3 \mathrm{~b} / \mathrm{C} 4 \mathrm{~b}$ receptor; DAF, decay-accelerating factor; DPPC, dipalmitoyl-phosphatidylcholine; DPPE, dipalmitoyl-phosphatidylethanolamine; DPPS, dipalmitoylphosphatidylserine; GVB, Veronal buffer containing $0.1 \%$ gelatin; $\mathrm{Hb}$ $\mathrm{S}$, hemoglobin S; Hb SS, hemoglobin S of homozygous individuals; MC540, merocyanine 540; MCP, membrane cofactor protein; NBD-PC, 1-acyl-2 [6-[(7-nitro-2-1,3-benzoxadiazol-4-yl)amino] caproyl]-sn-glycerol-3-phosphocholine; NBD-PE, 1-acyl-2-[6-[7nitro-2-1,3-benzoxadiazol-4-yl)amino] caproyl]-sn-glycerol-3- phosphoethanolamine; NBD-PS, 1-palmitoyl-2-[6-[7-nitro-2-1,3-benzoxyadiazol-4-yl)amino] caproyl]-sn-glycerol-3-phosphoserine; PC, phosphatidylcholine; PE, phosphatidylethanolamine; PS, phosphatidylserine; SCA, sickle cell anemia; VBS, Veronal buffer. 
factor (DAF, CD55) (25), membrane cofactor protein (MCP, CD46) (25), and the C3b/C4b receptor (CR1, CD35) (26). DAF, MCP, and CR 1 efficiently modulate complement activation by both the classical and alternative pathways by preventing the formation of $\mathrm{C} 3$ and $\mathrm{C} 5$ convertases on autologous cells and promoting the breakdown of bound $\mathrm{C} 4 \mathrm{~b}$ and $\mathrm{C} 3 \mathrm{~b}$ (2731 ). Of these, only DAF and CR 1 are found on erythrocytes.

The present work has tested the hypothesis that membrane phospholipid changes in deoxygenated sickle erythrocytes lead to complement activation through the alternative pathway. The results indicate that deoxygenated sickle erythrocytes activate the alternative complement pathway in autologous serum and that similar activation can be induced by several other treatments that increase PE and PS exposure on normal erythrocyte membranes. Complement activation occurs despite apparently normal membrane regulatory proteins, DAF and CR1. Analysis of cleaved complement factor B in plasma samples from SCA patients at baseline and in crisis and of bound C3 fragments on erythrocytes from hospitalized and nonhospitalized patients indicate that alternative pathway activation occurs in vivo during sickle crisis episodes.

\section{Methods}

SCA patients and normal donors. Venous blood was collected from individuals with $\mathrm{Hb}$ SS disease followed at the Duke University Comprehensive Sickle Cell Center's Adult Clinic at the time of routine visit to the clinic or from hospitalized patients for routine blood cell analysis. Homozygous hemoglobin A (Hb AA) donors were normal volunteers.

Erythrocytes. Sheep erythrocytes were purchased from the Colorado Serum Co. (Denver, $\mathrm{CO}$ ). Human and rabbit venous blood was drawn into EDTA-anticoagulated tubes. Human blood was diluted 1:7 with acid-citrate-dextrose solution and kept at $4^{\circ} \mathrm{C}$ for $<48 \mathrm{~h}$ before use in complement activation assays. Erythrocytes were washed and resuspended in veronal buffer solution (VBS; containing [mM] 150 sodium chloride, 3 sodium bicarbonate, 2.5 barbituric acid, and 1.5 sodium diethylbarbiturate, $\mathrm{pH} \mathrm{7.4)} \mathrm{before} \mathrm{each} \mathrm{experiment.} \mathrm{Human}$ erythrocyte preparations contained $<0.1 \%$ leukocytes as determined by flow cytometry using Simultest LeucoGATE ${ }^{\circledR}$ (Becton-Dickinson \& Co., Mountain View, CA).

Serum and plasma. Human plasma was prepared by centrifugation of citrated blood. Serum was isolated by centrifugation of blood collected into glass tubes and allowed to coagulate in vitro. Plasma and serum were stored in aliquots at $-70^{\circ} \mathrm{C}$ immediately after separation.

Complement components. Human factors B (32), H (33), P (34), and $\mathrm{C} 3$ (35), $\mathrm{Cl}$ (36), and factor $\mathrm{D}(37)$ were purified as described. Functionally purified factor I (35) was further purified on an affinity matrix prepared using goat antifactor I (Quidel, San Diego, CA) and CarboLink $^{\otimes}$ coupling gel (Pierce Chemical Co., Rockford, IL). Human C2 and C4 were purchased from Quidel. Purified C3 was labeled with [ ${ }^{125}$ I] sodium iodide (ICN Biochemicals, Inc., Costa Mesa, CA) to a specific activity of $\sim 0.1 \mu \mathrm{Ci} / \mu \mathrm{g}$ using Iodo-beads ${ }^{\otimes}$ (Pierce Chemical Co.).

Complement activation by human erythrocytes. Autologous serum containing $2.5 \mathrm{mM} \mathrm{MgCl} 2$ and $10 \mathrm{mM}$ EGTA to block the classical pathway and permit activation of the alternative pathway was added to an equal volume of erythrocyte suspension at a concentration of $10^{9}$ cells $/ \mathrm{ml}$. Control samples were incubated with autologous serum chelated with $10 \mathrm{mM}$ EDTA to block both complement pathways. Serum and erythrocyte mixtures were incubated for $30 \mathrm{~min}$ at $37^{\circ} \mathrm{C}$, washed with VBS containing $0.1 \%$ gelatin (GVB), and lysed in PBS containing either $0.5 \%$ Triton $\mathrm{X}-100$ or $0.5 \% \mathrm{NP}-40$. Samples were stored at $-70^{\circ} \mathrm{C}$ before testing $\mathrm{C} 3$ deposition.

The purified alternative complement pathway was prepared using $\mathrm{C} 3, \mathrm{MgCl}_{2}$, and factors $\mathrm{B}, \mathrm{D}, \mathrm{H}, \mathrm{I}$, and $\mathrm{P}$ at their physiological concen- trations in GVB as previously described (38). Human erythrocytes at $10^{9} \mathrm{cells} / \mathrm{ml}$ in VBS were incubated with an equal volume of the purified component mixture for $30 \mathrm{~min}$ at $37^{\circ} \mathrm{C}$. After incubation, erythrocytes were washed, lysed, and frozen before testing $\mathrm{C} 3$ deposition.

C3 binding assays. A competitive ELISA using horseradish peroxidase-conjugated anti-C3 antibody (Cappel Laboratories, Durham, NC) was used to quantitate $\mathrm{C} 3$ deposition on erythrocytes as previously described (21). The amount of $\mathrm{C} 3$ bound to erythrocytes was calculated from a standard curve prepared using $0.03-8 \mu \mathrm{g} / \mathrm{ml}$ purified C3. Values from EDTA controls were subtracted. The assay detects $\mathrm{C} 3 \mathrm{~d}$ as well as intact $\mathrm{C} 3, \mathrm{C} 3 \mathrm{~b}$, and $\mathrm{iC} 3 \mathrm{~b}$. The molecular weight of $\mathrm{C} 3 \mathrm{~b}$ was used to calculate molecules bound per cell. For experiments to assess the presence of $\mathrm{C} 3$ fragments on washed erythrocytes without serum incubation, washed erythrocytes were lysed at a concentration of $6.7 \times 10^{8}$ cells $/ \mathrm{ml}$ and added to the ELISA. Rabbit erythrocytes prepared in the same way were used to determine a negative control value, which was subtracted from the data.

The same washed erythrocytes were tested for the presence of $\mathrm{C} 3$ by a flow cytometric assay. $10^{8}$ erythrocytes were incubated with polyclonal goat anti-human C3 (Quidel) that had been affinity purified by absorption and elution from $\mathrm{C} 3 \mathrm{~b}$ bound to activated thiol Sepharose ${ }^{\otimes}$, washed with GVB, and incubated with FITC-conjugated rabbit antigoat IgG (Sigma Chemical Co., St. Louis, MO). Controls were incubated with second antibody only or with no antibody. Fluorescence was measured on an EPICS $C^{\circledR}$ fluorescence-activated cell sorter (Coulter Corp., Hialeah, FL). Staining observed with the FITC-conjugated secondary antibody was subtracted from staining observed with both antibodies for each sample using Immunoanalysis software (Coulter Corp.). Staining with the second antibody was not significantly greater than autofluorescence.

In vitro deoxygenation/oxygenation of erythrocytes. Human erythrocytes resuspended in VBS were gently bubbled with pure nitrogen (deoxygenated) or oxygen (oxygenated) at room temperature for 5 min. Erythrocyte suspensions were then incubated either sealed (deoxygenated) or not sealed (oxygenated) for $2 \mathrm{~h}$ at $37^{\circ} \mathrm{C}$. After incubation, cells were washed again and resuspended in VBS to a final concentration of $10^{9}$ cells $/ \mathrm{ml}$ before incubation in autologous serum.

Tetrathionate treatment of erythrocytes. Human erythrocytes from $\mathrm{Hb}$ AA donors were incubated with sodium tetrathionate, a thiol-oxidizing agent, as described (39). $1 \mathrm{ml}$ of packed erythrocytes was resuspended in $9 \mathrm{ml}$ of a buffer solution containing the following $(\mathrm{mM}): 90$ $\mathrm{KCl}, 45 \mathrm{NaCl}, 10$ sodium phosphate, and 44 sucrose ( $\mathrm{pH} 8.0$ ). Cell suspensions were incubated at $37^{\circ} \mathrm{C}$ with different concentrations of sodium tetrathionate for the times indicated in the results. After incubation, cells were washed and resuspended in the same buffer. A fluorescent probe, merocyanine 540 (MC540; Sigma Chemical Co.), was used to measure membrane phospholipid changes on sodium tetrathionatetreated erythrocytes as previously described (40). Increased binding of MC540 correlates with increased exposure of inner leaflet phospholipids containing unsaturated fatty acyl side chains on the outer leaflet of erythrocyte membranes (40) and has been shown to correlate with measurement of PE and PS exposure on erythrocytes by other methods. Cell suspensions were incubated with MC540 at a final concentration of $4 \mu \mathrm{g} / \mathrm{ml}$ for $4 \mathrm{~min}$ at room temperature. After incubation, the binding of MC540 was measured directly using a spectrofluorophotometer (Shimadzu Scientific Instruments, Inc., Columbia, MD) (excitation $\lambda, 570 \mathrm{~nm}$; emission $\lambda, 612 \mathrm{~nm}$ ).

Assay for total serum alternative complement pathway. Serum was assayed for alternative pathway activity by a hemolytic assay (41). Serum samples serially diluted in VBS containing $2.5 \mathrm{mM} \mathrm{MgCl}$ and $10 \mathrm{mM}$ EGTA were incubated with rabbit erythrocytes for $30 \mathrm{~min}$ at $37^{\circ} \mathrm{C}$. VBS containing $10 \mathrm{mM}$ EDTA was added to stop the activation, samples were centrifuged, and absorbance of supernatants was read at $541 \mathrm{~nm}$ for hemolysis. The serum dilutions resulting in $50 \%$ hemolysis $\left(\mathrm{CH}_{50}\right)$ were calculated as previously described $(41)$.

$D A F$ and $C R 1$ antigen levels. DAF and CR 1 expression on human erythrocytes were determined using anti-DAF mAb IIH6 (42), or anti-CR1 (Becton-Dickinson \& Co.) and FITC-conjugated $\mathrm{F}\left(\mathrm{ab}^{\prime}\right)_{2}$ 
goat anti-mouse IgG (Caltag, South San Francisco, CA) on a FACScan ${ }^{\circledR}$ flow cytometer.

Functional activity of $D A F$. DAF was purified from human erythrocytes as described (43). Purified DAF was incorporated into complement-activating liposomes containing dipalmitoyl-phosphatidylethanolamine (DPPE), dipalmitoyl-phosphatidylcholine (DPPC), and cholesterol (molar ratio 4:6:5) at a concentration of $1 \mu \mathrm{g}$ of DAF/ $\mu \mathrm{mol}$ phospholipid as previously described (44). Liposomes were incubated at $37^{\circ} \mathrm{C}$ for $1 \mathrm{~h}$ in the presence of $20 \mathrm{mM}$ sodium tetrathionate. After treatment, liposomes were incubated with normal human serum, washed, lysed, and C3 deposition was determined by ELISA. Tetrathionate-treated liposomes were compared with untreated liposomes containing or lacking DAF.

The functional activity of DAF in human erythrocytes was measured by its ability to inhibit the classical pathway $\mathrm{C} 3$ convertase, C4b2a (43). DAF inhibits this convertase by dissociating C2a from $\mathrm{C} 4 \mathrm{~b}(45)$. Human erythrocytes $\left(100 \mu \mathrm{l}\right.$ at $\left.10^{9} \mathrm{cells} / \mathrm{ml}\right)$ were incubated sequentially with rabbit anti-human erythrocyte serum (final concentration 1:1600)(Cappel Laboratories), human euglobulin $\mathrm{Cl}(20 \mu \mathrm{g})$, human $\mathrm{C} 4(4 \mu \mathrm{g})$, and human euglobulin $\mathrm{Cl}(20 \mu \mathrm{g})$, with washing between each step, to form huEAC14b. To assess $\mathrm{C} 3$ convertase function, $7.5 \mathrm{ng}$ oxidized human $\mathrm{C} 2$ ( $\left.{ }^{\text {oxy }} \mathrm{C} 2\right)(43,46)$ was added to 2.5 $\times 10^{7}$ huEAC14b in $50 \mu \mathrm{l} \mathrm{GVB}^{2+}$ (GVB containing $0.15 \mathrm{mM} \mathrm{CaCl}{ }_{2}$ and $0.5 \mathrm{mM} \mathrm{MgCl}$ ) and incubated for $5 \mathrm{~min}$ at $30^{\circ} \mathrm{C}$ to form the $\mathrm{C} 3$ convertase. Then $100 \mu \mathrm{l}$ of $\left[{ }^{125} \mathrm{I}\right] \mathrm{C} 3(50 \mu \mathrm{g})$ was added directly to the mixture in $100 \mu \mathrm{l}$ GVB containing $10 \mathrm{mM}$ EDTA (to prevent further convertase formation), and the cells were incubated for $30 \mathrm{~min}$ at $37^{\circ} \mathrm{C}$. After incubation, cells were washed three times and bound [ $\left.{ }^{125} \mathrm{I}\right] \mathrm{C} 3$ was determined by counting the pellets using a gamma counter (Minaxi ${ }^{\star}$; Packard Instruments Co. Inc., Downers Grove, IL). As controls, normal erythrocytes were incubated for $30 \mathrm{~min}$ on ice with anti-DAF mAbs (IA10, IIH6, and VIIIA7) $(42,43)$ to inhibit DAF function before incubation with rabbit anti-human erythrocyte antibody, $\mathrm{C} 1, \mathrm{C} 4$, and $\mathrm{C} 2$, and measurement of $\left[{ }^{125} \mathrm{I}\right] \mathrm{C} 3$ binding. AntiDAF treatment did not affect the amount of $\mathrm{C} 4$ bound to the erythrocytes after antibody, $\mathrm{C} 1$, and $\mathrm{C} 4$ incubations.

Functional activity of CR1. The function of CR 1 was determined by its cofactor activity for factor I-dependent cleavage of bound $\mathrm{C} 3 \mathrm{~b}$ $(47,48) .10^{7}$ sheep erythrocytes with bound $\left[{ }^{125} \mathrm{I}\right] \mathrm{C} 3 \mathrm{~b}$ deposited by the classical pathway as described (48) were incubated with $2 \times 10^{7}$ human erythrocytes in the presence of $1 \mu \mathrm{g}$ of purified factor I for $30 \mathrm{~min}$ at $37^{\circ} \mathrm{C}$. After incubation, supernatants were analyzed by $5-15 \%$ gradient SDS-PAGE and autoradiography. CR1 function on erythrocytes from different individuals was compared by the density of the released $27-\mathrm{kD} \mathrm{C} 3 \mathrm{c}$ fragment on the autoradiograph.

Insertion of phospholipids into erythrocytes. Synthetic dipalmitoylphosphatidylserine (DPPS) was purchased from Sigma Chemical Co. Synthetic DPPC and DPPE were purchased from Calbiochem Corp. (La Jolla, CA ). 1 - Palmitoyl - 2 - [6 - [ ( 7 - nitro - 2 - 1, 3 - benzoxadiazol-4yl)amino]caproyl]-sn-glycerol-3-phosphoserine(NBD-PS), 1-acyl-2-[6-[(7-nitro-2-1,3-benzoxadiazol-4-yl)amino]caproyl]-snglycerol-3-phosphocholine (NBD-PC), and 1-acyl-2-[6-[(7-nitro2-1,3-benzoxadiazol-4-yl)amino] caproyl]-sn-glycerol-3-phosphoethanol-amine (NBD-PE) were purchased from Avanti Polar Lipids, Inc. (Alabaster, $\mathrm{AL}$ ).

Phospholipid mixtures made of DPPC/NBD-PC, DPPS/NBD-PS, or DPPE/NBD-PE with molar ratio 4:1, 4:1, and 29:1 respectively, were dissolved in pure chloroform and dried under nitrogen. Vesicles were then prepared by sonication of $5 \mu \mathrm{g} / \mathrm{ml}$ (DPPC/NBD-PC and DPPS/NBD-PS) or $30 \mu \mathrm{g} / \mathrm{ml}$ (DPPE/NBD-PE) in PBS for $10 \mathrm{~min}$ at room temperature with a probe sonicator (Ultrasonic Power; Freeport, IL) as described (8). Contaminating large multilamellar vesicles were removed from the suspension by centrifugation at $2,000 \mathrm{~g}$ for $15 \mathrm{~min}$.

Phospholipid vesicles were incubated with erythrocyte suspensions for $30 \mathrm{~min}$ at $37^{\circ} \mathrm{C}(8)$. After incubation, erythrocytes were washed and resuspended at $10^{9}$ cells $/ \mathrm{ml}$ in VBS before autologous serum incubation. The mean channel fluorescence of treated erythrocytes was measured by flow cytometry using fluorescein settings. Phospholipid incorporation was then calculated from standard curves of mean channel fluorescence versus incorporation for each phospholipid. To construct the standard curves, phospholipid incorporation for a range of vesicle/erythrocyte ratios was determined by fluorimetry of fully dequenched unincorporated vesicles compared with pure phospholipid standards (excitation $\lambda, 470 \mathrm{~nm}$; emission $\lambda, 525 \mathrm{~nm}$ ) and plotted against the mean channel fluorescence readings of the erythrocytes. Insertion of labeled lipid into erythrocyte membranes was confirmed by visual observation of bright uniform rings of membrane fluorescence in treated cells. To determine whether adherent vesicles were present in the treated erythrocyte preparations, fluorescence (excitation $\lambda, 470 \mathrm{~nm}$; emission $\lambda, 525 \mathrm{~nm}$ ) of treated erythrocytes was determined in the presence and absence of $2 \%$ Triton X-100. Because of the self-quenching properties of the labeled phospholipids, the phospholipid vesicles show about a 10-fold increase in fluorescence after lysis (8). Lipid that has inserted into the erythrocyte membrane by contrast is dequenched by dilution with membrane lipids and its fluorescence is not increased by detergent solubilization. The erythrocytes used for complement activation studies did not show increased fluorescence after lysis, indicating minimal contamination with intact vesicles.

Plasma $\mathrm{Bb}$. Plasma $\mathrm{Bb}$ concentration was measured using a commercial ELISA from Quidel. Paired plasma samples were obtained from three SCA patients at baseline and during acute sickle crisis episodes. Patients were considered to be at baseline if they had no pain or fever at the time of presentation and returned a postcard $48 \mathrm{~h}$ later stating that they had not experienced pain or fever in the $48 \mathrm{~h}$ after their samples were drawn. Patients were considered to have pain crisis when they presented to the emergency department or clinic with pain that was consistent with their usual sickle cell pain crisis; no other cause was found for the pain; and there was no resolution of pain after $8 \mathrm{~h}$ of treatment with parenteral narcotics. Five additional plasma samples from three other SCA patients with chronic pain were also analyzed.

Statistical analysis. Comparisons between means were made using the $t$ test with $P<0.05$ considered to be significantly different.

\section{Results}

Activation of the alternative complement pathway by deoxygenated erythrocytes from SCA patients. Deoxygenated or oxygenated erythrocytes obtained from SCA patients during routine clinic visits and healthy controls were incubated with MgEGTA-treated autologous serum and alternative pathway activation determined by $\mathrm{C} 3$ deposition (Fig. 1). C3 was

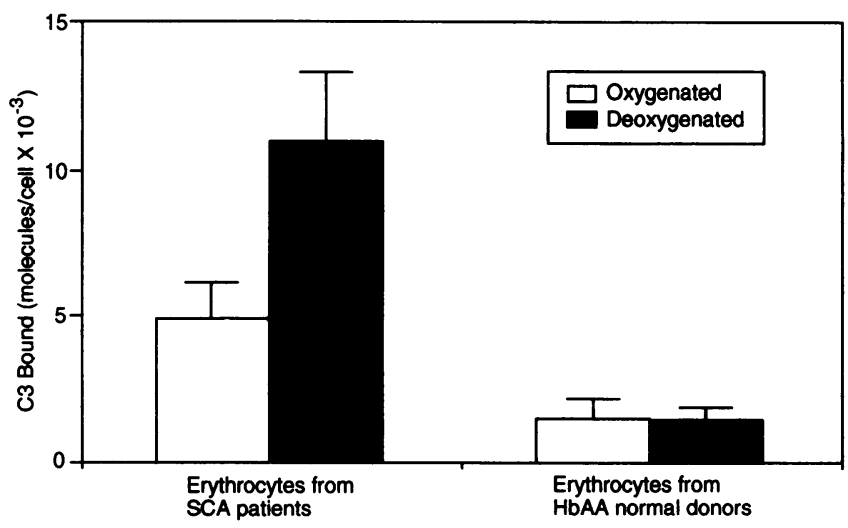

Figure 1. Alternative pathway activation in autologous serum by deoxygenated sickle erythrocytes. Erythrocytes from normal donors or SCA patients were incubated with MgEGTA-treated autologous serum after in vitro deoxygenation or oxygenation. Cells were washed, lysed, and deposited C3 was measured by a competitive ELISA. The means \pm SEM are shown for nine SCA patients and four normal donors. 
bound to erythrocytes from homozygous $\mathrm{Hb}$ SS patients ( $n$ $=9$ ), and there was a more than twofold increase in C3 bound on deoxygenated compared with oxygenated erythrocytes. No hemolysis was observed after serum incubation. Hb AA erythrocytes $(n=4)$ showed very little complement activation after the same deoxygenation or oxygenation treatments. The C3 deposition required in vitro complement activation since only a minimal amount of $\mathrm{C} 3$ was detected on sickle or normal erythrocytes after incubation with EDTA-treated serum (data not shown). Values for erythrocytes incubated with EDTAtreated serum were $<1,000$ molecules/cell and have been subtracted from the data shown. Oxygenated sickle erythrocytes showed greater $\mathrm{C} 3$ binding than Hb AA erythrocytes, which may be due to senescent or irreversibly sickled erythrocytes within the total erythrocyte population. The $\mathrm{C} 3$ bound to sickle erythrocytes was found to be predominantly $\mathrm{C} 3 \mathrm{~b}$ and / or iC $3 \mathrm{~b}$ by substituting mouse mAb 129 , which recognizes specifically human $\mathrm{C} 3 \mathrm{~b}$ and $\mathrm{iC} 3 \mathrm{~b}$ (38) for the polyclonal anti-C3 antibody in the ELISA.

Total alternative pathway levels in serum from SCA patients. Since previous reports have shown decreased alternative pathway activity in serum from SCA patients $(16,49,50)$, the functional activity of the alternative pathway was determined by hemolysis of rabbit erythrocytes. The total alternative pathway activity in $\mathrm{CH}_{50}$ units was $3.93 \pm 0.22 \mathrm{U} / \mathrm{ml}$ for serum from SCA patients $(n=9)$ and $3.77 \pm 0.22 \mathrm{U} / \mathrm{ml}$ for serum from normal donors $(n=8)$. These values for healthy SCA patients and normal donors did not differ significantly $(P>0.05)$.

Membrane phospholipid changes and activation of the alternative complement pathway after tetrathionate treatment of $H b A A$ erythrocytes. Incubation of normal erythrocytes with thiol-oxidizing agents, including sodium tetrathionate and diamide, results in increased PE and PS exposure on the outer membrane leaflet $(39,51)$ similar to the phospholipid changes observed in deoxygenated erythrocytes from $\mathrm{Hb}$ SS patients. To determine whether altered membrane phospholipid distri-

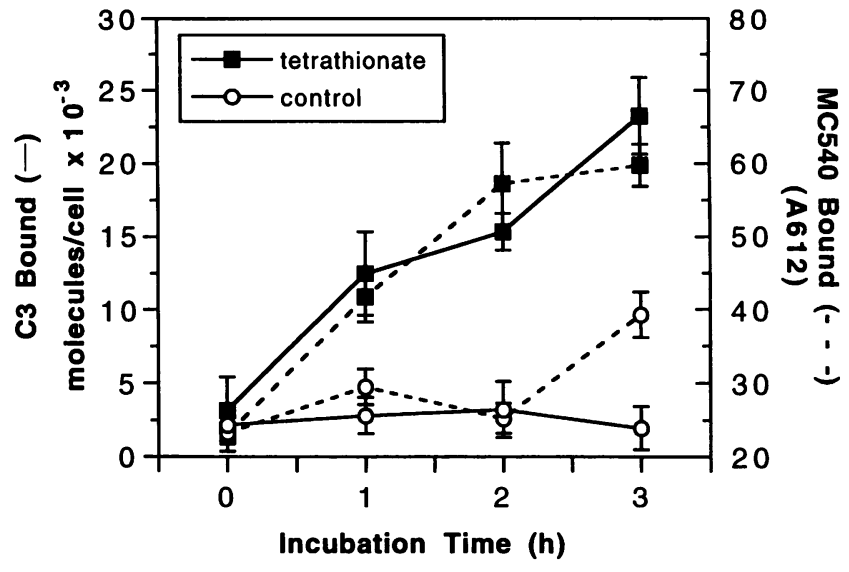

Figure 2. Membrane phospholipid redistribution and complement activation on normal erythrocytes after treatment with sodium tetrathionate. Erythrocytes were treated with $5 \mathrm{mM}$ sodium tetrathionate or buffer for $0,1,2$, or $3 \mathrm{~h}$ at $37^{\circ} \mathrm{C}$. MC540 binding that correlates with $\mathrm{PE}$ and PS exposure was measured fluorimetrically (dotted lines). Treated erythrocytes were incubated with MgEGTA-treated autologous serum, washed, lysed, and deposited $\mathrm{C} 3$ was measured by a competitive ELISA (solid lines). Circles are buffer-treated erythrocytes. Squares are tetrathionate-treated erythrocytes. Means \pm SEM are shown for four experiments.

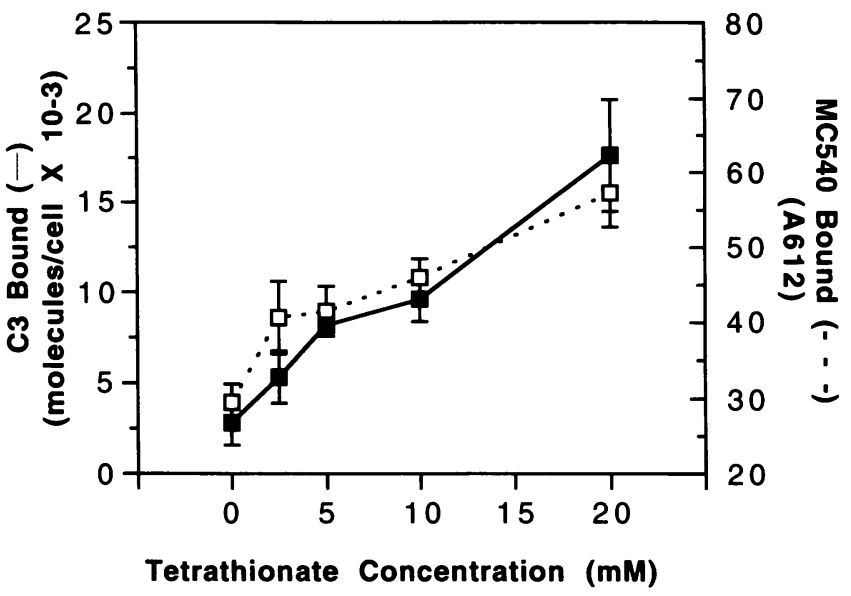

Figure 3. Membrane phospholipid redistribution and complement activation on normal erythrocytes after treatment with sodium tetrathionate. Erythrocytes were treated with $0-20 \mathrm{mM}$ sodium tetrathionate for $1 \mathrm{~h}$ at $37^{\circ} \mathrm{C}$. MC540 binding that correlates with PE and PS exposure was measured fluorimetrically (open squares, dotted lines). Treated erythrocytes were incubated with MgEGTA-treated autologous serum, washed, lysed, and deposited $\mathrm{C} 3$ was measured by a competitive ELISA (closed squares, solid lines). Means \pm SEM are shown for four experiments.

bution in normal erythrocytes would induce complement activation, $\mathrm{Hb}$ AA erythrocytes were treated with $5 \mathrm{mM}$ sodium tetrathionate for $0-3 \mathrm{~h}$ or with $2.5-20 \mathrm{mM}$ sodium tetrathionate for $1 \mathrm{~h}$ at $37^{\circ} \mathrm{C}$. Membrane phospholipid changes were monitored by fluorimetry using MC540, which binds to inner leaflet phospholipids. Increased binding of MC540 has been shown to correlate with exposure of PE and PS (40). MC540 binding increased with incubation time (Fig. 2) and sodium tetrathionate concentration (Fig. 3). A corresponding increase in complement activation by tetrathionate-treated erythrocytes after incubation in MgEGTA-treated autologous serum was observed (Figs. 2 and 3 ). Erythrocytes from the same donors incubated in buffer showed little increase in MC540 binding or $\mathrm{C} 3$ deposition.

Activation of the purified alternative pathway by tetrathionate-treated and sickle erythrocytes. Naturally occurring antibody that binds to clustered band 3 on senescent and diamidetreated erythrocytes has been reported to enhance complement activation (52). To determine whether antibody was required for complement activation by tetrathionate-treated erythrocytes, erythrocytes from $\mathrm{Hb}$ AA normal donors were treated with $5 \mathrm{mM}$ tetrathionate for $3 \mathrm{~h}$ or $20 \mathrm{mM}$ tetrathionate for $1 \mathrm{~h}$ and $\mathrm{C} 3$ deposition measured after incubation with the six purified components of the alternative pathway. As shown in Fig. 4 $a$, tetrathionate-treated erythrocytes activated complement in this purified mixture in the absence of antibody. Deoxygenated sickle erythrocytes also activated complement after incubation with purified alternative pathway components (Fig. $4 \mathrm{~b}$ ). Tetrathionate-treated erythrocytes activated complement in serum that had been absorbed with tetrathionate-treated erythrocytes to remove antibody to band 3 or other erythrocyte molecules (data not shown).

Antigenic and functional levels of DAF and CRI in sickle and tetrathionate-treated erythrocytes. To determine whether decreased levels or activities of regulatory proteins contributed to the complement activation observed after deoxygenation or 

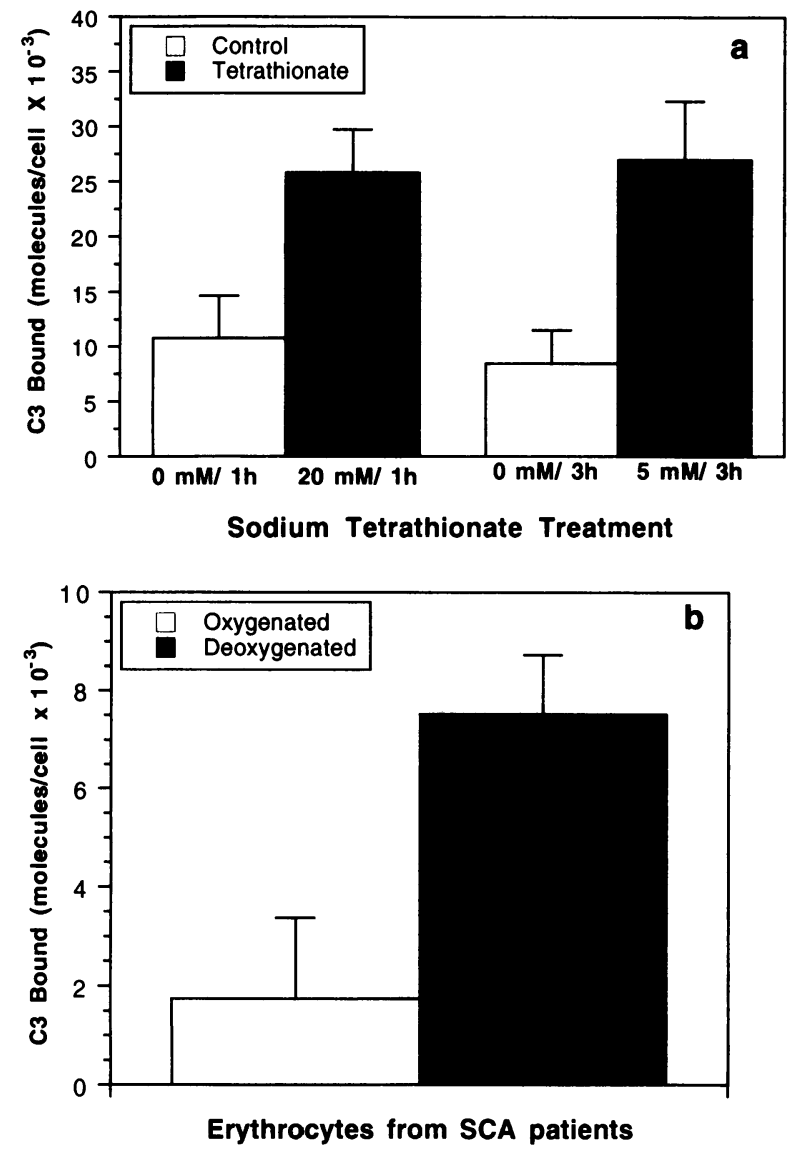

Figure 4. Activation of the purified alternative pathway by $(a)$ erythrocytes treated with sodium tetrathionate or $(b)$ erythrocytes from SCA patients, deoxygenated or oxygenated in vitro. Erythrocytes were incubated with purified alternative pathway components after in vitro treatments. Cells were washed and lysed, and deposited $\mathrm{C} 3$ was measured by a competitive ELISA. In $a$, open bars are control cells incubated in the same buffer without sodium tetrathionate. Means \pm SEM are shown for three experiments.

tetrathionate treatment, the antigenic and functional levels of DAF and CR 1 were studied. As shown in Table I, antigenic levels of DAF and CR1 on erythrocytes were not different in erythrocytes from SCA and normal donors and were not changed by in vitro deoxygenation or tetrathionate treatment.

To test for a direct effect of tetrathionate treatment on DAF function, liposomes composed of PE, PC, and cholesterol were prepared with and without incorporated DAF. Liposomes without DAF activated the alternative complement pathway and showed $\mathrm{C} 3$ binding ( $3.7 \mu \mathrm{g} / \mu \mathrm{mol}$ phospholipid) after serum incubation (Fig. 5). DAF inhibited C3 binding by liposomes of the same composition by $84 \%$. DAF inhibited C3 binding by $96 \%$ after treatment of liposomes with $20 \mathrm{mM}$ tetrathionate for $1 \mathrm{~h}$, demonstrating that purified DAF is not inactivated by sodium tetrathionate treatment.

The functional activity of membrane DAF was also measured in deoxygenated sickle and tetrathionate-treated erythrocytes by its ability to inhibit the classical pathway $\mathrm{C} 3$ convertase ( Table II ). DAF dissociates the classical pathway C3 convertase, decreasing $\mathrm{C} 3$ binding to the cells as shown by the dramatic increase in $\left[{ }^{125} \mathrm{I}\right] \mathrm{C} 3$ binding to human erythrocytes treated with anti-DAF before formation of the convertase. To control for possible differences in convertase formation, bound C4 was assayed by ELISA on lysed samples of cells before incubation with $\mathrm{C} 3$. There were no differences in bound $\mathrm{C} 4$ for any groups including anti-DAF-treated cells (342 C4 molecules/ cell) compared with untreated controls (400 molecules/cell). Deoxygenated sickle erythrocytes did not show significantly greater $\mathrm{C} 3$ binding than oxygenated sickle erythrocytes or erythrocytes from normal donors. Treatment of normal erythrocytes with $20 \mathrm{mM}$ tetrathionate for $1 \mathrm{~h}$ (Table II) or $5 \mathrm{mM}$ tetrathionate for $3 \mathrm{~h}$ (data not shown) also did not increase C3 binding compared with control cells. Thus, complement activation did not correlate with decreased DAF function.

The cofactor function of erythrocyte membrane CR 1 was tested by incubating sheep erythrocytes bearing $\left[{ }^{125} \mathrm{I}\right] \mathrm{C} 3 \mathrm{~b}$ with human erythrocytes and purified factor I and measuring the release of the cleavage product $\mathrm{C} 3 \mathrm{c}$. $\mathrm{CR} 1$ cofactor activity on deoxygenated sickle erythrocytes from six patients and tetrathionate-treated normal erythrocytes was not different from the activity of erythrocytes from normal donors (Fig. 6 and Table III). C $3 \mathrm{c}$ release required both factor I and human erythrocytes (data not shown).

Alternative pathway activation after insertion of $P E$ and $P S$ into normal erythrocytes. As a method of altering membrane phospholipid composition without disrupting the cytoskeleton, normal erythrocytes were incubated with synthetic phospholipid vesicles to increase PE, PS, or PC concentration in the membrane. Insertion was measured with fluorescent phospholipids. As shown in Fig. 7, Hb AA erythrocytes activated the alternative pathway in autologous serum after insertion of low concentrations of PE or higher concentrations of PS, but not

Table I. Antigenic Levels of DAF and CRI on Erythrocytes Determined by Flow Cytometry Using Monoclonal Anti-DAF and Anti-CRI Antibodies

\begin{tabular}{|c|c|c|c|c|c|}
\hline Donors & Treatment & DAF* & $n$ & $\mathrm{CR} 1^{*}$ & $n$ \\
\hline Normal donors & None & $288 \pm 8$ & 4 & $108 \pm 35$ & 3 \\
\hline SCA patients & Deoxygenation & $290 \pm 10$ & 10 & $90 \pm 3$ & 9 \\
\hline SCA patients & Oxygenation & $296 \pm 9$ & 10 & $106 \pm 6$ & 9 \\
\hline Normal donors & $20 \mathrm{mM}$ Tetrathionate for $1 \mathrm{~h}$ & $319 \pm 21$ & 4 & $77 \pm 16$ & 3 \\
\hline Normal donors & Buffer control for $1 \mathrm{~h}$ & $314 \pm 18$ & 4 & $77 \pm 21$ & 3 \\
\hline Normal donors & $5 \mathrm{mM}$ Tetrathionate for $3 \mathrm{~h}$ & $320 \pm 22$ & 4 & $72 \pm 14$ & 3 \\
\hline Normal donors & Buffer control for $3 \mathrm{~h}$ & $303 \pm 19$ & 4 & $68 \pm 20$ & 3 \\
\hline
\end{tabular}

* Mean channel fluorescence \pm SEM. 


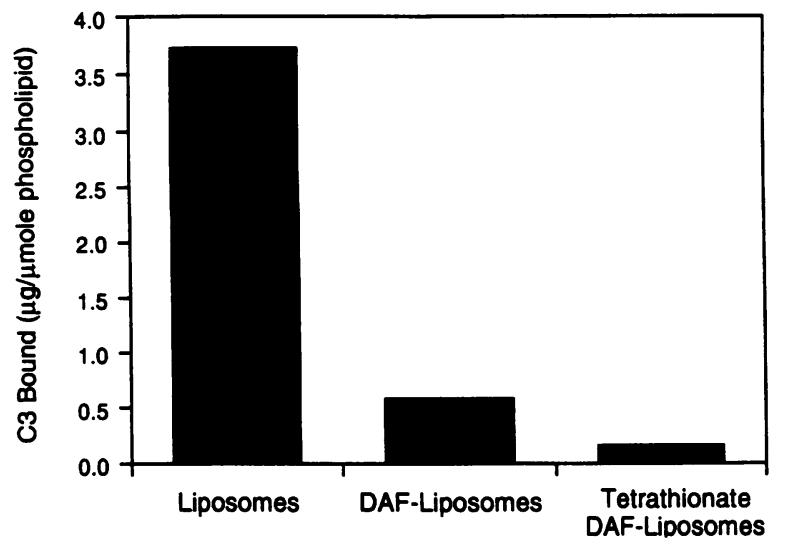

Figure 5. Functional activity of purified DAF after tetrathionate treatment. Purified DAF was incorporated into liposomes containing DPPE, DPPC, and cholesterol (molar ratio 4:6:5) at a concentration of $1 \mu \mathrm{g}$ of DAF / $\mu \mathrm{mol}$ phospholipid. DAF-containing liposomes were incubated at $37^{\circ} \mathrm{C}$ for $60 \mathrm{~min}$ in the presence of $20 \mathrm{mM}$ sodium tetrathionate. After treatment, liposomes were incubated with normal human serum, washed, lysed, and $\mathrm{C} 3$ deposition was determined by ELISA. Tetrathionate-treated liposomes containing DAF were compared with untreated liposomes containing or lacking DAF. Means of duplicate samples are shown.

PC. In these experiments, the maximum amount of PE insertion was $2 \mu \mathrm{g} / 10^{9}$ cells whereas the insertion for PC and PS reached a final concentration of $>13 \mu \mathrm{g} / 10^{9}$ cells. These maximum incorporation levels represent increases of $\sim 2 \%$ of total PE and $18 \%$ of total PS, calculated as described $(4,8)$. No hemolysis was observed after phospholipid insertion at these concentrations. Adherent intact liposomes were not detected in the erythrocyte preparations by measurement of fluorescence dequenching after lysis (see Methods).

Evidence for in vivo alternative complement pathway activation in SCA patients. To determine whether complement activation occurs in vivo in SCA, plasma samples from SCA patients and normal donors were tested for the presence of cleaved factor $\mathbf{B}(\mathrm{Bb})$. $\mathrm{Bb}$ is generated from factor $\mathbf{B}$ by factor $D$ during formation of the alternative pathway $\mathrm{C} 3$ convertase. Previous analyses in our laboratory have found a mean plasma $\mathrm{Bb}$ concentration of $0.70 \pm 0.18 \mu \mathrm{g} / \mathrm{ml}$ for 12 normal donors. In the present study plasma samples obtained from three normal $\mathrm{Hb}$ AA donors assayed on the same plate as the SCA samples showed a Bb concentration of $1.44 \pm 0.34 \mu \mathrm{g} / \mathrm{ml}$ (Fig. 8). Paired plasma samples isolated from three SCA patients demonstrated a twofold higher $\mathrm{Bb}$ fragment concentration in crisis compared with baseline $(P=0.037)$. Bb levels in samples from SCA patients at baseline were not significantly higher than normal controls $(P>0.05)$. Five SCA patients characterized clinically as suffering from chronic pain also showed increased plasma $\mathrm{Bb}$ concentrations compared with normal controls ( $P$ $=0.001$ ).

Erythrocytes with bound fragments of $\mathrm{C} 3$ (C3d and C3dg) have been reported in several hemolytic anemias and systemic autoimmune diseases (53). Although initial experiments indicated that the amount of $\mathrm{C} 3$ bound to cells from healthy SCA patients was very low, we examined erythrocytes from a larger number of hospitalized and nonhospitalized SCA patients for bound $\mathrm{C} 3$ using the competitive C3 ELISA (Fig. 9) and flow cytometry with anti-C3 antibody. The results of both assays showed significantly increased C3 on erythrocytes from patients compared with controls. By ELISA, control erythrocytes had an average of $74 \pm 23 \mathrm{C} 3$ molecules per cell, erythrocytes from outpatients had $369 \pm 122$ C3 molecules per cell, and erythrocytes from hospitalized patients had $855 \pm 147 \mathrm{C} 3$ molecules per cell. These values were significantly higher for hospitalized patients compared with controls $(P=0.0001)$, hospitalized patients compared with outpatients $(P=0.028)$, and outpatients compared with controls $(P=0.021)$. By flow cytometry erythrocytes from hospitalized patients and outpatients had a significantly higher percentage of cells stained by anti-C3 antibody and significantly higher mean fluorescence of the positive cells compared with erythrocytes from normal donors (data not shown). These results and the $\mathrm{Bb}$ data (Fig. 8 ) indicate that alternative pathway activation in SCA patients correlates with periods of crisis and that SCA erythrocytes are involved in this activation.

\section{Discussion}

This study demonstrates activation of the alternative complement pathway in autologous serum by deoxygenated sickle erythrocytes. Several lines of evidence indicate that this complement activation is the result of the increased appearance of $P E$ and PS in the outer membrane leaflet of these cells.

Alternative pathway activation is initiated by the binding of C3b to surfaces $(19,20)$. The bound C3b then assembles the alternative pathway $\mathrm{C} 3$ convertase, $\mathrm{C} 3 \mathrm{bBb}$, by the binding of factor $B$ and its cleavage by factor $D$. The $C 3$ convertase cleaves additional C3 creating a positive amplification loop for the deposition of $\mathrm{C} 3 \mathrm{~b}$ on the activating surface. Membrane-bound $\mathrm{C} 3 \mathrm{~b}$ molecules facilitate phagocytosis and can further activate C5 through C9 to form lytic membrane attack complexes. The alternative pathway is a tightly regulated system in which inter-

Table II. The Functional Activity of Erythrocyte Membrane DAF Assayed by Inhibition of C3 Convertase Activity

\begin{tabular}{llll}
\hline Donors & \multicolumn{1}{c}{ Treatment } & C3 bound* & $n$ \\
\hline $\begin{array}{c}\text { Normal } \\
\text { donors }\end{array}$ & Anti-DAF mAbs ${ }^{\ddagger}$ & $199,455 \pm 42,857$ & 9 \\
$\begin{array}{c}\text { Normal } \\
\text { donors }\end{array}$ & None & $3,566 \pm 846$ & 10 \\
$\begin{array}{c}\text { SCA } \\
\text { patients }\end{array}$ & Deoxygenation & $3,667 \pm 1,260$ & 4 \\
$\begin{array}{c}\text { SCA } \\
\text { patients }\end{array}$ & Oxygenation & $4,114 \pm 1,020$ & 4 \\
$\begin{array}{c}\text { Normal } \\
\text { donors }\end{array}$ & 20 mM Tetrathionate for $1 \mathrm{~h}$ & $5,874 \pm 2,288$ & 6 \\
$\begin{array}{c}\text { Normal } \\
\text { donors }\end{array}$ & Buffer control for $1 \mathrm{~h}$ & $3,156 \pm 100$ & 6 \\
\hline
\end{tabular}

* cpm \pm SEM. Human erythrocytes were treated with rabbit antibody, human $\mathrm{Cl}, \mathrm{C} 4$, and ${ }^{\text {oxy }} \mathrm{C} 2$ to form a $\mathrm{C} 3$ convertase. DAF function was determined by inhibition of $\left[{ }^{125} \mathrm{I}\right] \mathrm{C} 3$ binding. There was no significant difference in $\mathrm{C} 3$ binding between sickle and normal erythrocytes, between deoxygenated and oxygenated sickle erythrocytes, or between normal or buffer control and sodium tetrathionate-treated erythrocytes (all $P>0.05$ ). ${ }^{\ddagger}$ Erythrocytes were pretreated with three anti-DAF mAbs to inhibit DAF function. 


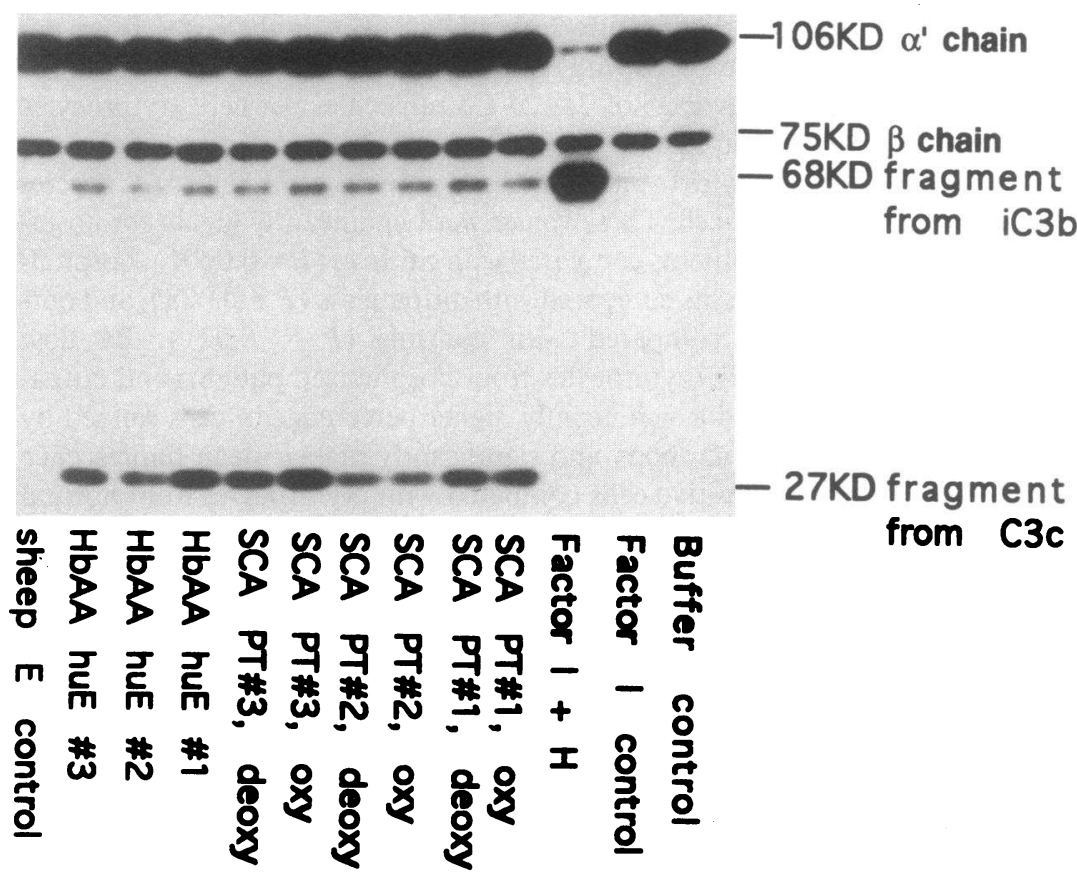

Figure 6. Functional activity of $\mathrm{CR} 1$ on $\mathrm{Hb} \mathrm{AA}$ and $\mathrm{Hb}$ SS erythrocytes. $10^{7}$ sheep erythrocytes with bound ${ }^{125}[\mathrm{I}] \mathrm{C} 3 \mathrm{~b}$ were incubated for $30 \mathrm{~min}$ at $37^{\circ} \mathrm{C}$ with $1 \mu \mathrm{g}$ purified factor I and $2 \times 10^{7}$ normal erythrocytes or sickle erythrocytes after in vitro deoxygenation or oxygenation. Cells were centrifuged and supernatants were analyzed by $5-15 \%$ gradient SDS-PAGE and autoradiography for cleavage of $\mathrm{C} 3 \mathrm{~b}$. Control lanes were ${ }^{125}[\mathrm{I}] \mathrm{C} 3 \mathrm{~b}$ sheep erythrocytes incubated with buffer alone, factor I alone, factor I and $5 \mu \mathrm{g} \mathrm{H}$ (to produce iC3b), and factor I and sheep E (lacking CR1). Results of this and additional experiments are summarized in Table III. actions between the activating surface, $\mathrm{C} 3 \mathrm{~b}$, and regulatory proteins determine whether amplification will take place.

Previous results from our laboratory (21) and others (22, 23,54 ) have shown that liposomes containing PE or PE and PS or inside-out vesicles prepared from erythrocytes activate the alternative complement pathway. Thus, it seemed possible that

Table III. The Functional Activity of Erythrocyte Membrane CRI Assayed by Cofactor Activity of the Cleavage of C 3 b by Factor I

\begin{tabular}{llll}
\hline Donors & \multicolumn{1}{c}{ Treatment } & C3c released ${ }^{*}$ & $n$ \\
\hline $\begin{array}{c}\text { Normal } \\
\text { donors }\end{array}$ & None & $3.185 \pm 0.281$ & 4 \\
$\begin{array}{c}\text { SCA } \\
\text { patients }\end{array}$ & Deoxygenation & $3.027 \pm 0.197$ & 6 \\
$\begin{array}{c}\text { SCA } \\
\text { patients }\end{array}$ & Oxygenation & $3.125 \pm 0.254$ & 6 \\
$\begin{array}{c}\text { Normal } \\
\text { donors }\end{array}$ & 20 mM Sodium tetrathionate for $1 \mathrm{~h}$ & $4.372 \pm 0.287$ & 6 \\
$\begin{array}{c}\text { Normal } \\
\text { donors }\end{array}$ & Buffer control for $1 \mathrm{~h}$ & $4.747 \pm 0.164$ & 6 \\
$\begin{array}{c}\text { Normal } \\
\text { donors }\end{array}$ & 5 mM Tetrathionate for $3 \mathrm{~h}$ & $4.084 \pm 0.334$ & 4 \\
$\begin{array}{c}\text { Normal } \\
\text { donors }\end{array}$ & Buffer control for $3 \mathrm{~h}$ & $4.342 \pm 0.278$ & 6 \\
\hline
\end{tabular}

* Density of $27-\mathrm{kD}$ band \pm SEM. Sheep erythrocytes were treated with rabbit antibody, human $\mathrm{C} 1, \mathrm{C} 4,{ }^{0 x y} \mathrm{C} 2$, and $\left[{ }^{125} \mathrm{I}\right] \mathrm{C} 3$. Erythrocytes were assayed for $\mathrm{CR} 1$ cofactor activity by adding human erythrocytes to the sheep cell intermediates in the presence of factor I. Released $\mathrm{C} 3 \mathrm{c}$ was analyzed by the appearance of a $27-\mathrm{kD}$ band from $\mathrm{C} 3 \mathrm{c}$ in supernatant samples by SDS-PAGE and autoradiography. There was no significant difference in CR1 activity between sickle and normal erythrocytes, between deoxygenated and oxygenated sickle erythrocytes, or between control and sodium tetrathionate-treated erythrocytes (all $P>0.05)$. the membrane phospholipid changes associated with deoxygenation of sickle erythrocytes (3-5) were responsible for the complement activation we observed when these cells were incubated with autologous serum. In support of this hypothesis, two other treatments that increase PE and PS exposure were shown to cause complement activation by normal erythrocytes. Thiol-oxidizing agents, including sodium tetrathionate and diamide, induce membrane phospholipid redistribution by disruption of the cytoskeleton (55) whereas incubation of erythrocytes with lipid vesicles can increase phospholipid concentrations by incorporation of the phospholipids from the vesicles into cell membranes $(8,56)$. Normal erythrocytes acti-

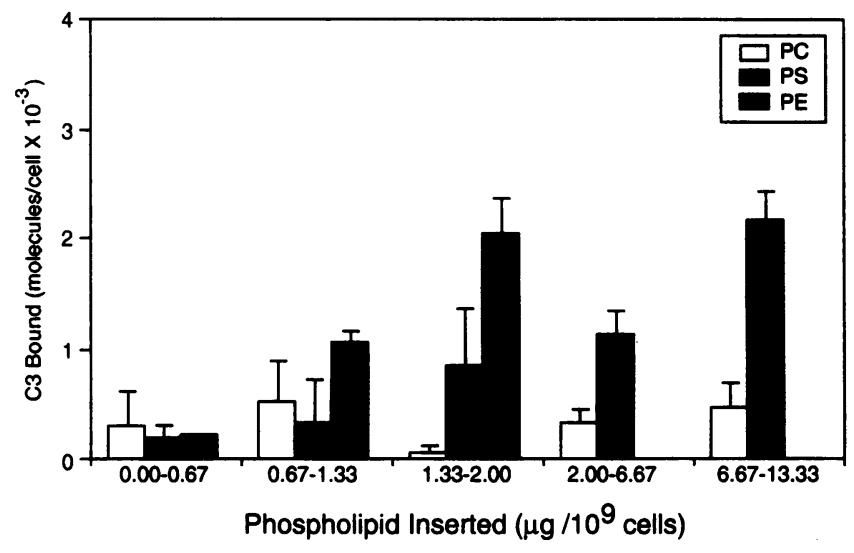

Figure 7. Alternative pathway activation in autologous serum by normal erythrocytes after incubation with PC, PS, or PE vesicles. Erythrocytes from four normal donors were incubated with trace-labeled PC, PS, or PE and incorporation of phospholipids was determined by flow cytometry. Erythrocytes were then incubated with MgEGTA-treated autologous serum. Cells were washed, lysed, and bound $\mathrm{C} 3$ was measured by a competitive ELISA. The $\mathrm{C} 3$ bound is shown for erythrocytes grouped by the amount of phospholipid inserted. The maximum PE incorporated was $2 \mu \mathrm{g} / 10^{9}$ cells. 
vated complement after either sodium tetrathionate treatment or incubation with PE or PS.

Thiol-oxidizing agents have also been used to study human erythrocyte senescence. It has been reported that treatment with diamide leads to the binding of naturally occurring antibody to aggregated band 3 and that this induces complement activation through the alternative pathway (52). Antibody was not required for complement activation by sickle or tetrathionate-treated erythrocytes, since both showed C3 deposition after incubation with purified alternative pathway components in the absence of antibody. Preabsorption of serum with tetrathionate-treated erythrocytes also did not prevent activation by tetrathionate-treated cells. Since the erythrocytes were separated from serum before deoxygenation or tetrathionate treatment, and antibody binding requires aggregation of membrane proteins, it is unlikely that antibody was already bound to the cells. These results and those using inserted phospholipids indicate that phospholipid changes can induce complement activation in the absence of antibody.

Both PE and PS are exposed on tetrathionate-treated and deoxygenated sickle erythrocytes. Deoxygenation of sickle erythrocytes increases outer leaflet PE from 12 to $\sim 40 \%$ of the total membrane PE and PS from 0 to $\sim 20 \%$ of the total membrane PS (3-5). The use of labeled individual phospholipids allowed comparison of the effects of PE and PS on complement activation. Although PE was poorly incorporated, probably because of its inability to form bilayered vesicles, an increase of 1.3-2 $\mu \mathrm{g} \mathrm{PE} / 10^{9}$ erythrocytes (representing an increase of $\sim 2 \%$ of the total PE) in normal erythrocyte membranes resulted in increased complement activation. A dose-dependent increase in $\mathrm{C} 3$ deposition was observed for erythrocytes with 1.3-13 $\mu$ g PS incorporated for $10^{9}$ erythrocytes, but this increase was only significant for erythrocytes containing 6.7-13 $\mu \mathrm{g}$ PS $/ 10^{9}$ erythrocytes. This represents an increase of $9-18 \%$ of the total membrane PS and is similar to the concentration found on deoxygenated sickle erythrocytes. In contrast, PC insertion did not induce complement activation at the same con-

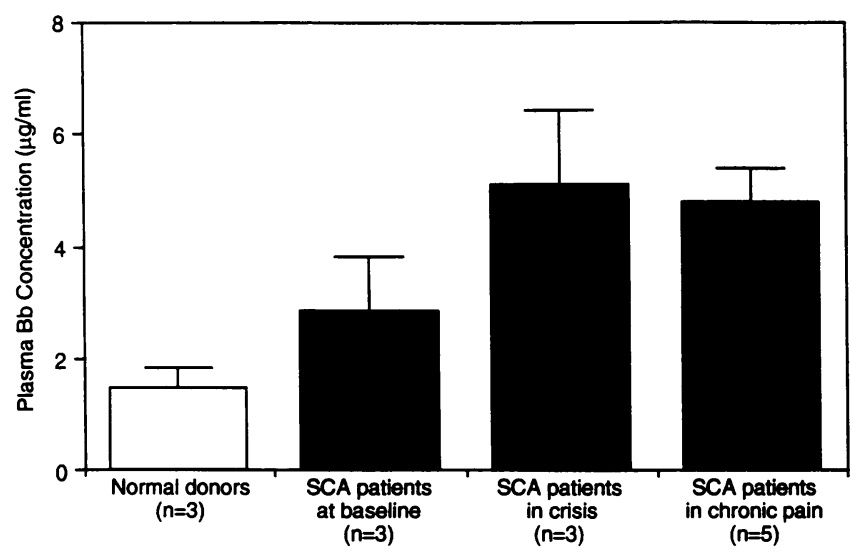

Figure 8. Fragment $\mathrm{Bb}$ levels in plasma from normal donors and SCA patients at baseline, in crisis, or in chronic pain. Citrated plasma samples from normal donors or SCA patients were assayed by a commercial ELISA for fragment $\mathrm{Bb}$ to measure of in vivo alternative pathway activation. Plasma $\mathrm{Bb}$ concentrations for SCA patients in crisis are significantly higher than $\mathrm{Bb}$ levels of normal donors or SCA patients at baseline $(P=0.037)$. Values for SCA patients in chronic pain are also significantly higher than normal $(P=0.001)$.

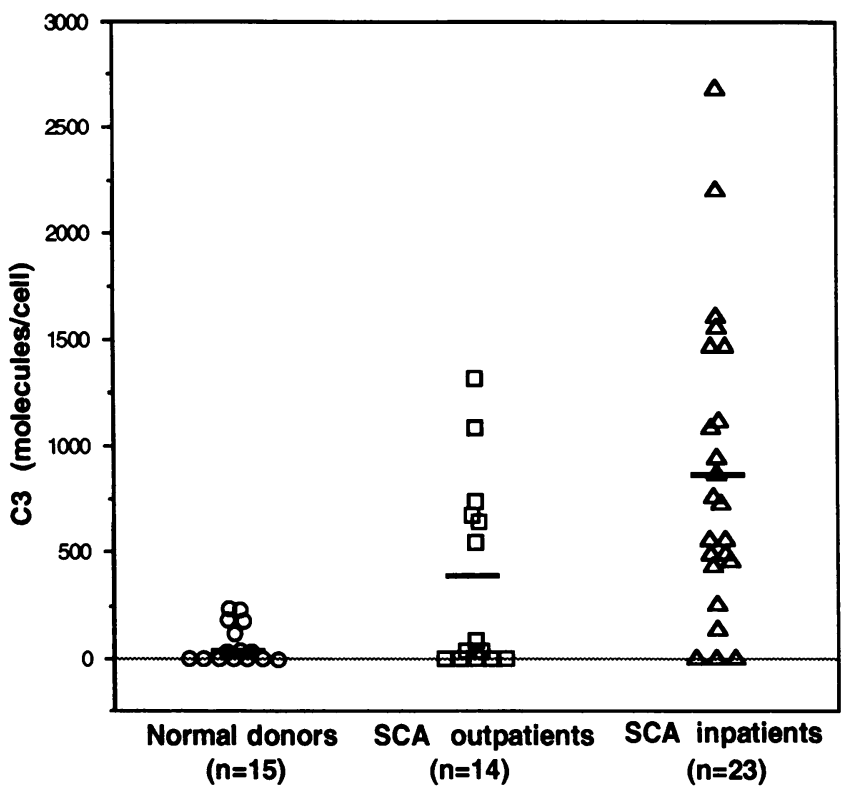

Figure 9. C3 levels on erythrocytes from normal donors, SCA patients seen as outpatients, and hospitalized SCA patients. Erythrocytes were washed, lysed, and tested for $\mathrm{C} 3$ by competitive ELISA. Mean values of $\mathrm{C} 3$ bound to erythrocytes for 23 hospitalized patients (SCA inpatients) ( $855 \pm 147$ molecules/cell) and 14 SCA outpatients ( $369 \pm 122$ molecules/cell) were significantly higher than those of 15 normal donors ( $74 \pm 23$ molecules/cell).

centrations ( $\geq 13 \mu \mathrm{g} / 10^{9}$ erythrocytes). The amount of C3 bound per cell in the phospholipid insertion experiments was lower than that observed with sickle or tetrathionate-treated erythrocytes. However, as noted, the concentrations of PE inserted were also much lower than the amount of PE exposed by the treatments, and possible combined effects of PE and PS were not examined. On the basis of these studies and previous studies using liposomes (21-24), complement activation is apparently more sensitive to PE exposure than to PS exposure. In contrast, PS has been implicated in activation of the coagulation pathway and in binding of erythrocytes to monocytes (2, 7-9).

Complement activation on autologous cells is normally blocked by membrane regulatory proteins. On erythrocytes there are two membrane proteins that regulate $C 3$ convertases, DAF (43) and CR1 (26). DAF is a phosphatidylinositol-anchored membrane protein, which promotes the dissociation of C3 convertases, preventing further complement activation (57). CR1 is a receptor for complement-fixing immune complexes (26). CR1 can also dissociate both C3 convertases and act as a cofactor for the factor I-mediated degradation of $\mathrm{C} 3 \mathrm{~b}$ and $\mathrm{C} 4 \mathrm{~b}$ molecules generated by either the classical or alternative pathway. Several additional membrane proteins act on the membrane attack complex to prevent lysis. Since there was no indication of lysis of erythrocytes by the treatments used in these experiments, the functional activities of these regulatory proteins are apparently sufficient to prevent lysis despite the deposition of $\mathrm{C} 3 \mathrm{~b}$.

No modification of the function of DAF was observed after incubation of liposomes containing purified DAF with sodium tetrathionate, indicating that the treatment did not directly inactivate DAF. No significant changes in antigenic level or in 
the function of DAF and CR 1 were detected in sickle or tetrathionate-treated erythrocytes. This is consistent with the low levels of C3 found on erythrocytes isolated from healthy SCA patients before deoxygenation and serum incubation. Increased bound $\mathrm{C} 3$ in the form of $\mathrm{C} 3 \mathrm{~d}$ and $\mathrm{C} 3 \mathrm{dg}$ has been reported in conditions of ongoing complement activation associated with reduced CR1 or DAF levels (53). This also indicates that in vitro complement activation by sickle and tetrathionate-treated erythrocytes resulted from the increased appearance of activators rather than decreased function of regulatory proteins. The degree to which complement activation may have been limited by the regulatory proteins was not determined in these experiments. Studies in liposomes in which inserted PE leads to complement activation have demonstrated that this activation is sensitive to inhibition by DAF (44).

Previous studies (15-18) have found evidence of ongoing complement activation in SCA patients. For the most part, no cause of the complement activation was hypothesized, although one study (15) reported a correlation between C3d levels and hemoglobin and suggested that intravascular hemolysis leads to complement activation in these patients. We have demonstrated here an increase in factor $\mathrm{Bb}$ concentration in the plasma obtained from three SCA patients experiencing sickle crisis compared with matched baseline values. SCA patients suffering from chronic pain also showed increased plasma $\mathrm{Bb}$ compared with normal donors. Since $\mathrm{Bb}$ is generated during the formation of the alternative pathway $\mathrm{C} 3$ convertase, it is a direct indication of in vivo complement activation during sickle crisis. The plasma $\mathrm{Bb}$ levels correlated with increases in fibrin fragment D dimer (a product of fibrinolysis) in identical plasma samples during sickle crisis (Phillips, G., unpublished results). Earlier reports have demonstrated, by using erythrocyte ghosts (54), liposomes (58), or sickle erythrocytes (7), that exposure of membrane PS enhances clotting activities, which may in turn activate the fibrinolytic pathway. The coincident elevation of factor $\mathrm{Bb}$ fragment and fragment $\mathrm{D}$ dimer suggests that phospholipid redistribution induced in sickle erythrocytes by low oxygen tension leads to the activation of both fibrinolytic and complement cascades, which could recruit additional factors contributing to acute painful sickle crisis.

In addition, hospitalized SCA patients were found to have increased amounts of $\mathrm{C} 3$ or C3 fragments bound to erythrocytes in vivo. Exposure of PE and PS on sickle erythrocytes is expected to occur during sickle crisis due to deoxygenation resulting from vasoocclusion. Thus these results are consistent with the hypothesis that altered membrane phospholipids on sickle erythrocytes cause complement activation in vivo. The amount of $\mathrm{C} 3$ detected by ELISA on control erythrocytes (74 \pm 23 molecules/cell) was similar to a previously reported value of $50 \pm 23$ molecules/cell (53). The levels of $C 3$ found on erythrocytes from hospitalized SCA patients ( $855 \pm 147$ molecules/cell), although higher than controls, are much lower than the mean of $8,673 \pm 7,151$ molecules/cell found on erythrocytes from patients with cold agglutinin disease, an autoantibody-mediated hemolytic anemia.

Complement activation may also contribute to the decreased resistance to bacterial infections in SCA patients. Although we did not find decreased complement in serum from SCA patients studied at baseline, we did find evidence of activation during crisis. In addition, phagocytosis of sickle erythrocytes by macrophages after complement activation (59) or by direct recognition of exposed PS (8) may overload the phagocytic clearance system, preventing its normal function in the removal of invading microorganisms.

Erythrocyte membrane phospholipid redistribution is not unique to sickle erythrocytes. Increased exposure of PE and PS has been reported in senescent or aged erythrocytes $(60)$, erythrocytes from chronic myeloid leukemia patients $(61)$, and malaria-infected erythrocytes (62). For some of these conditions, there is evidence for complement activation as well $(63,64)$. Increased PS has been shown to enhance senescent erythrocyte adherence to phagocytes and endothelial cells $(2,8,9)$. We have found that human red blood cells aged in vitro can activate the alternative complement pathway resulting in increased C3 deposition (Wang, R., unpublished results). Malaria-infected erythrocytes have increased exposure of $\mathrm{PE}$ and PS (62), increased surface C3 binding, and increased phagocytosis by macrophages (59).

In summary, we have presented evidence that altered membrane phospholipid distribution on human erythrocytes is sufficient to initiate complement activation perhaps contributing to opsonization and clearance of abnormal erythrocytes in SCA and other conditions.

\section{Acknowledgments}

The authors thank Nelda Mold for facilitating the transfer of patient samples.

This work was supported by National Institutes of Health grants AI-24720 to Dr. Mold, AI-23598 and PO1 DK-3818 to Dr. Medof, and NP60 HL-28391 to Dr. Phillips of the Duke University-University of North Carolina Comprehensive Sickle Cell Center.

\section{References}

1. Murayama, M., and R. M. Nalbandian. 1973. Sickle Cell Hemoglobin; Molecule to Man. Little, Brown and Company, Boston.

2. Hebbel, R. 1991. Beyond hemoglobin polymerization: the red blood cell membrane and sickle disease pathophysiology. Blood. 77:214-237.

3. Lubin, B., D. Chiu, J. Bastacky, B. Roelofson, and L. L. M. van Deenan. 1981. Abnormalities in membrane phospholipid organization in sickle erythrocytes. J. Clin. Invest. 67:1643-1649.

4. Wagner, G. M., R. S. Schwartz, D. T.-Y. Chiu, and B. H. Lubin. 1985. Membrane phospholipid organization and vesiculation of erythrocytes in sickle cell anemia. Clin. Haematol. 14:183-200.

5. Lubin, B., F. Kuypers, and D. Chiu. 1989. Red cell membrane lipid dynamics. In The Red Cell: Seventh Ann Arbor Conference. G. J. Brewer, editor. Alan R. Liss, Inc., New York. 507-524.

6. Op den Kamp, J. A. F. 1979. Lipid asymmetry in membranes. Annu. Rev. Biochem. 48:47-71.

7. Chiu, D., B. Lubin, B. Roelofson, and L. L. M. Van Deenen. 1981. Sickled erythrocytes accelerated clotting in vitro: an effect of abnormal membrane lipid asymmetry. Blood. 58:-398-401.

8. Schwartz, R. S., Y. Tanaka, I. J. Fidler, D. T.-Y. Chiu, B. Lubin, and A. Schroit. 1985. Increased adherence of sickled and phosphatidylserine-enriched human erythrocytes to cultured human peripheral blood monocytes. J. Clin. Invest. 75:1965-1972.

9. Hebbel, R. P., R. S. Schwatz, and N. Mohandas. 1985. The adhesive sickle erythrocyte: cause and consequence of abnormal interactions with endothelium, monocytes/macrophages and model membranes. Clin. Haematol. 14:141-161.

10. Wong, Y. W., D. R. Powers, L. Chan, A. Hiti, C. Johnson, and G. Overturf. 1992. Polysaccharide encapsulated bacterial infection in sickle cell anemia: a thirty year epidemiologic experience. Am. J. Hematol. 39:176-182.

11. Pearson, H. A., R. P. Spencer, and E. A. Cornelius. 1969. Functional asplenia in sickle-cell anemia. N. Engl. J. Med. 281:923-926.

12. Winkelstein, J. A., and R. H. Drachman. 1968. Deficiency of pneumococcal serum opsonizing activity in sickle-cell disease. N. Engl. J. Med. 279:459-466.

13. Johnston, R. B., Jr., S. L. Newman, and A. G. Struth. 1973. An abnormality of the alternate pathway of complement activation in sickle cell disease. $N$. Engl. J. Med. 288:803-808. 
14. Bjornson, A. B., M. H. Gaston, and C. L. Zellner. 1977. Decreased opsonization for Streptococcus pneumoniae in sickle cell disease: studies on selected complement components and immunoglobulins. J. Pediatr. 91:371-378.

15. De Ceulaer, K., W. Wilson, A. A. G. Morgan, and G. R. Serjeant. 1981. Plasma haemoglobin and complement activation in sickle cell disease. J. Clin. Lab. Immunol. 6:57-60.

16. deCiutiis, A. C., C. M. Peterson, M. J. Polley, and L. J. Metakis. 1978. Alternate pathway activation in sickle cell disease and b-thalassemia major. $J$. Natl. Med. Assoc. 70:503-506.

17. Chudwin, D. S., A. D. Korenblit, M. Kingzette, S. Artrip, and S. Rao. 1985. Increased activation of the alternative complement pathway in sickle cell disease. Clin. Immunol. Immunopathol. 37:93-97.

18. Wilson, W. A., E. J. Thomas, and J. P. G. Sissons. 1979. Complement activation in asymptomatic patients with sickle cell anaemia. Clin. Exp. Immunol. 36:130-139.

19. Joiner, K. A., E. J. Brown, and M. M. Frank. 1984. Complement and bacteria: chemistry and biology in host defense. Annu. Rev. Immunol. 2:461-491.

20. Pangburn, M. K. 1988. Initiation and activation of the alternative pathway of complement. In Cytolytic Lymphocytes and Complement: Effects of the Immune System. E. R. Podack, editor. CRC Press, Boca Raton, FL. 41-56.

21. Mold, C. 1989. Effect of membrane phospholipids on activation of the alternative complement pathway. J. Immunol. 143:1663-1668.

22. Comis, A., and S. B. Easterbrook-Smith. 1986. Inhibition of serum complement haemolytic activity by lipid vesicles containing phosphatidylserine. FEBS (Fed. Eur. Biochem. Soc.) Lett. 197:321-327.

23. Chonn, A., P. R. Cullis, and D. V. Devine. 1991. The role of surface charge in the activation of the classical and alternative pathways of complement by liposomes. J. Immunol. 146:4234-4241.

24. Tomasko, M. A., and D. S. Chudwin. 1988. Complement activation in sickle cell disease: a liposome model. J. Lab. Clin. Med. 112:248-253.

25. Lublin, D. M., and J. P. Atkinson. 1990. Decay-accelerating factor and membrane cofactor protein. Curr. Topics Microbiol. Immunol. 153:123-145.

26. Ross, G. D., and M. E. Medof. 1985. Membrane complement receptors specific for bound fragments of C3. Adv. Immunol. 37:217-267.

27. Seya, T., T. Hara, M. Matsumoto, Y. Sugita, and H. Akeda. 1990. Complement-mediated tumor cell damage induced by antibodies against membrane cofactor protein (MCP, CD46). J. Exp. Med. 172:1673-1680.

28. Oglesby, T. J., C. J. Allen, M. K. Liszewski, D. J. G. White, and J. P. Atkinson. 1992. Membrane cofactor protein (CD46) protects cells from complement-mediated attack by an intrinsic mechanism. J. Exp. Med. 175:1547-1551.

29. Medof, M. E., T. Kinoshita, R. Silber, and V. Nussenzweig. 1985. Amelioration of lytic abnormalities of paroxysmal nocturnal hemoglobinuria with decay-accelerating factor. Proc. Nat. Acad. Sci. USA. 82:2980-2984.

30. Fearon, D. T. 1979. Regulation of the amplification C3 convertase of human complement by an inhibitory protein isolated from human erythrocyte membrane. Proc. Nat. Acad. Sci. USA. 76:5867-5871.

31. Holguin, M. H., C. B. Martin, N. J. Bernshaw, and C. J. Parker. 1992. Analysis of the effects of activation of the alternative pathway of complement on erythrocytes with an isolated deficiency of decay accelerating factor. J. Immunol. 148:498-502.

32. Hunsicker, L. G., S. Ruddy, and K. F. Austen. 1973. Alternative complement pathway: factors involved in cobra venom factor (CoVF) activation of the third component of complement (C3). J. Immunol. 110:128-138.

33. Hong, K., T. Kinoshita, Y. Dohi, and K. Inoue. 1982. Effect of trypsinization on the activity of human factor H. J. Immunol. 129:647-652.

34. Smith, C. A., M. K. Pangburn, C.-W. Vogel, and H. J. Müller-Eberhard. 1984. Molecular architecture of human properdin, a positive regulator of the alternative pathway of complement. J. Biol. Chem. 259:4582-4588.

35. Hammer, C. H., G. H. Wirtz, L. Renfe, H. D. Gresham, and B. F. Tack. 1981. Large scale isolation of functionally active components of the human complement system. J. Biol. Chem. 256:3995-4006.

36. Lachmann, P. J., and M. J. Hobart. 1978. Complement technology. In Handbook of Experimental Immunology. D. M. Weir, editor. Blackwell Scientific Publications, Oxford, England. 5A.1-5A.23.

37. Catana, E., and J. A. Schifferli. 1991. Purification of human complement factor $\mathrm{D}$ from the peritoneal fluid of patients on chronic ambulatory peritoneal dialysis. J. Immunol. Methods. 138:265-271.

38. Mold, C., G. R. Nemerow, B. M. Bradt, and N. R. Cooper. 1988. CR2 is a complement activator and the covalent binding site for $\mathrm{C} 3$ during alternative pathway activation by RAJI cells. J. Immunol. 140:1923-1929.

39. Haest, C. W. M., and B. Deuticke. 1975. Experimental alteration of phospholipid-protein interactions within the human erythrocyte membrane. Biochem. Biophys. Acta. 401:468-480.

40. Williamson, P., J. Bateman, K. Kozarsky, K. Mattocks, N. Hermanowicz, H.-R. Choe, and R. A. Schlegel. 1982. Involvement of spectrin in the maintenance of phase-state asymmetry in the erythrocyte membrane. Cell. 30:725-733.

41. Gewurz, A. T., T. F. Lint, S. M. Imherr, S. S. Garber, and H. Gewurz.
1982. Detection and analysis of inborn and acquired complement abnormalities. Clin. Immunol. Immunopathol. 23:297-311.

42. Kinoshita, T., M. E. Medof, R. Silber, and V. Nussenzweig. 1985. Distribution of decay accelerating factor in the peripheral blood of normal individuals and patients with paroxysmal nocturnal hemoglobinuria. J. Exp. Med. 162:7592.

43. Medof, M. E., T. Kinoshita, and V. Nussenzweig. 1984. Inhibition of complement activation on the surface of cells after incorporation of decay-accelerating factor (DAF) into their membranes. J. Exp. Med. 160:1558-1578.

44. Mold, C., E. L. Walter, and M. E. Medof. 1990. The influence of membrane components on regulation of alternative pathway activation by decay-accelerating factor. J. Immunol. 145:3836-3841.

45. Fujita, T., T. Inoue, K. Ogawa, K. lida, and N. Tamura. 1987. The mechanism of action of decay-accelerating factor (DAF). DAF inhibits the assembly of C 3 convertases by dissociating C2a and Bb. J. Exp. Med. 166:1221-1228.

46. Polley, M. J., and H. J. Müller-Eberhard. 1967. Enhancement of the hemolytic activity of the second component of human complement by oxidation. J. Exp. Med. 126:1013-1025.

47. Mold, C., B. M. Bradt, G. R. Nemerow, and N. R. Cooper. 1988. EpsteinBarr virus regulates activation and processing of the third component of complement. J. Exp. Med. 168:949-969.

48. Medof, M. E., K. Iida, C. Mold, and V. Nussenzweig. 1982. Unique role of the complement receptor $\mathrm{CR} 1$ in the degradation of $\mathrm{C} 3 \mathrm{~b}$ associated with immune complexes. J. Exp. Med. 156:1739-1754.

49. Wilson, W. A., and E. J. Thomas. 1979. Activation of the alternative pathway of human complement by haemoglobin. Clin. Exp. Immunol. 36:140144.

50. De Ceulair, K., W. A. Wilson, A. G. Morgan, and G. R. Serjeant. 1981 Plasma haemoglobin and complement activation in sickle cell disease. J. Lab. Clin. Immunol. 6:57-60.

51. Haest, C. W. M., and B. Deuticke. 1976. Possible relationship between membrane proteins and phospholipid asymmetry in the human erythrocyte membrane. Biochem. Biophys. Acta. 436:353-365.

52. Lutz, H. U., F. Bussolino, R. Flepp, S. Fasler, P. Stammler, M. D. Kazatchkine, and P. Arese. 1987. Naturally occurring anti-band-3 antibodies and complement together mediate phagocytosis of oxidatively stressed human erythrocytes. Proc. Natl. Acad. Sci. USA. 84:7368-7372.

53. Ross, G. D., W. J. Yount, M. J. Walport, J. B. Winfield, C. J. Parker, C. R. Fuller, R. P. Taylor, B. L. Myones, and P. J. Lachmann. 1985. Disease-associated loss of erythrocyte complement receptors (CR 1, C3b receptors) in patients with systemic lupus erythematosus and other diseases involving autoantibodies and/ or complement activation. J. Immunol. 135:2005-2014.

54. Feola, M., J. Simoni, R. Tran, C. D. Lox, and P. C. Canizaro. 1989. The toxicity of erythrocyte stroma. In The Red Cell: Seventh Ann Arbor Conference. G. J. Brewer, editor. Alan R. Liss, Inc., New York. 361-382.

55. Haest, C. W. M., G. Plasa, D. Kamp, and B. Deuticke. 1978. Spectrin as a stabilizer of the phospholipid asymmetry in the human erythrocyte membrane Biochem. Biophys. Acta. 509:21-32.

56. Tanaka, Y., and A. J. Schroit. 1983. Insertion of fluorescent phosphatidylserine into the plasma membrane of red blood cells. J. Biol. Chem. 258:1133511343

57. Nicholson-Weller, A., J. Burge, D. T. Fearon, P. F. Weller, and K. F. Austen. 1982. Isolation of a human erythrocyte membrane glycoprotein with decay-accelerating activity for $\mathrm{C} 3$ convertases of the complement system. $\mathrm{J}$. Im munol. 129:184-189.

58. Frank, P. F. H., E. M. Bevers, B. H. Lubin, P. Comfurius, D. T.-Y. Chiu, J. A. F. Op den Kamp, R. F. A. Zwaal, L. L. M. Van Deenen, and B. Roelofsen 1985. Uncoupling of the membrane skeleton from the lipid bilayer. J. Clin. Invest. 75:183-190.

59. Arese, P., F. Turrini, F. Bussolino, H. U. Lutz, D. Chiu, L. Zuo, F. Kuypers, and H. Ginsburg. 1991. Recognition signals for phagocytic removal of favic malaria-infected and sickled erythrocytes. In Red Blood Cell Aging. M. Magnani and A. De Flora, editors. Plenum Press, New York. 317-327.

60. Shukla, S. D., and D. J. Hanahan. 1982. Membrane alterations in cellular aging: susceptibility of phospholipids in density (age)-separated human erythrocytes to phospholipase. Arch. Biochem. Biophys. 214:335-341.

61. Kumar, A., and C. M. Gupta. 1983. Red cell membrane abnormalities in chronic myeloid leukaemia. Nature (Lond.). 303:632-633.

62. Maguire, P. A., J. Prudhomme, and I. W. Sherman. 1991. Alterations in erythrocyte membrane phospholipid organization due to the intracellular growth of the human malaria parasite, Plasmodium flaciparum. Parasitology. 102:179186

63. Freedman, J. 1984. Membrane-bound immunoglobulins and complement components on young and old red cells. Transfusion (Arlingt.). 24:477481 .

64. Lutz, H. U. 1990. Erythrocyte Clearance. In Blood Cell Biochemistry. J. R. Harris, editor. Plenum Press, New York. 81-120. 